\title{
Analisis Penambahan Dexmedetomidine pada Operasi Besar Tulang Belakang Elektif di RSUD Dr. Soetomo
}

\author{
Putri Rizkiya, Nancy Margarita R, Bambang Harijono, Lilik Herawati \\ Departemen Anestesiologi dan Reanimasi Fakultas Kedokteran Universitas Airlangga-RSUD Dr. Soetomo \\ Surabaya
}

\begin{abstract}
Abstrak
Latar Belakang dan Tujuan: Dexmedetomidine (DEX) suatu agonis $\alpha 2$, telah banyak digunakan untuk mengendalikan respon stress pembedahan melalui penekanan respon simpatis dan endokrin. Studi ini bertujuan untuk menganalisis efek penambahan dexmedetomidine terhadap kadar kortisol, nadi, tekanan arteri rerata, kebutuhan penggunaan fentanyl dan isoflurane pada operasi tulang belakang.

Metode: Sebuah studi randomisasi terkontrol tersamar ganda dilakukan pada pasien yang menjalani operasi besar tulang belakang elektif di RSUD Dr. Soetomo, Surabaya. Nadi, tekanan arteri rerata, kebutuhan fentanyl dan isoflurane serta perubahan kadar kortisol pre dan post-operatif dibandingkan antara pasien yang memperoleh dexmedetomidine (DEX) dan placebo (SAL).

Hasil: Nadi dan tekanan arteri rerata lebih stabil pada kelompok DEX pada saat intubasi, prone positioning dan insisi. Perubahan kadar kortisol pada kelompok DEX $(9,9 \pm 5,2 \mathrm{mcg} / \mathrm{dl})$ lebih rendah dibanding kelompok SAL $(11.7 \pm 8.4 \mathrm{mcg} / \mathrm{dl})$ namun tidak berbeda bermakna secara statistik $(\mathrm{p}=0.88)$. Penggunaan fentanyl dan isofluran pada kelompok DEX dapat dikurangi masing-masing 50\% $(\mathrm{p}=0,00)$ dan 30\% $(\mathrm{p}=0,00)$. Kecepatan pulih sadar kelompok DEX lebih cepat. $(\mathrm{p}=0,001)$

Simpulan: Hemodinamik yang stabil, berkurangnya penggunaan opioid dan anestesi inhalasi serta proses pulih sadar yanglebihcepatpadakelompokDEXmendukungpenggunaandexmedetomidine dalamoperasibesartulangbelakang.
\end{abstract}

Kata kunci: dexmedetomidine, fentanyl, isoflurane, kortisol, operasi tulang belakang

JNI 2020, 9 (2): 78-86

\section{Analysis of Dexmedetomidine Addition in Elective Major Spinal Surgery in RSUD Dr. Soetomo}

\begin{abstract}
Background and Objective: Dexmedetomidine (DEX) an $\alpha 2$ agonist, is widely used to control stress response during surgery through inhibition of sympathetic and endocrine response. This study aims to analyze the effect of dexmedetomidine addition towards blood cortisol level, pulse rate, mean arterial pressure, and fentanyl and isoflurane use during major spinal surgery.

Method: A randomized doubleblind controlled study was conducted on twenty patients undergoing major spinal surgery in RSUD dr. Soetomo, Surabaya. Pulse rate, mean arterial pressure, fentanyl and isoflurane used, and plasma cortisol changes were compared between patients receiving dexmedetomidine (DEX) and placebo (SAL). Results: Pulse rate and mean arterial pressure was more stable in DEX group during intubation, prone positioning and incision. Changes in cortisol level in DEX group $(9.9 \pm 5.2 \mathrm{mcg} / \mathrm{dl})$ was lower, but not statistically significant fromSAL group $(11.7 \pm 8.4 \mathrm{mcg} / \mathrm{dl}, \mathrm{p}=0.88)$. Fentanyl and isoflurane use in DEX group was reduced $50 \%(\mathrm{p}=0.00)$ and $30 \%(p=0.00)$ respectively. Recovery time in DEX group was faster $(\mathrm{p}=0.001)$.

Conclusion: Hemodinamik stability, reduced opioid and inhalational anesthesia use, and faster anesthesia recovery time supports dexmedetomidine as anadjunct in general anesthesia in major spinal surgery.
\end{abstract}

Key words: cortisol, dexmedetomidine, fentanyl, isoflurane, major spinal surgery

JNI 2020, 9 (2): 78-86

This article is licensed under

Creative Commons Attribution-NonCommercial-ShareAlike 4.0 International License.

CPutri Rizkiya, Nancy Margaretta R, Bambang H, Lilik Herawati (2020)

under the CC-BY-NC-SA license 


\section{Pendahuluan}

Pembedahan tulang belakang berkembang sangat pesat, dimana juga diimbangi dengan kerumitan prosedur operasi yang tinggi. Jumlah pembedahan tulang belakang di RSUD dr. Soetomo didapatkan cukup tinggi, yakni 192 pembedahan pada tahun 2015 dan 188 pada tahun 2016. Hal ini menjadi tantangan tersendiri bagi ahli anestesi untuk dapat mengembangkan teknik anestesi konvensional menjadi suatu rangkaian teknik yang lebih menguntungkan dan aman bagi pasien dan ahli bedah. ${ }^{1}$

Metode perioperatif multidisiplin telah banyak dikembangkan untuk meningkatkan hasil akhir dari pembedahan, diantaranya adalah enhanced recovery programs (ERPs) atau enhanced recovery after surgery (ERAS). Konsep utama dari protokol ini adalah meminimalisasi respon stres pembedahan melalui pemilihan prosedur dan obat anestesi serta analgesia perioperatif., ${ }^{2,3}$ Operasi besar tulang belakang didefinisikan sebagai fusi komplek (fusi spinal 360 derajat dengan insisi tunggal, kombinasi pendekatan teknik anterior dengan transverse atau teknik fusi posterior, serta fusi 2 atau lebih level diskus), beberapa literatur juga memasukkan fusi sederhana (pendekatan operasi tunggal dan fusi 1-2 level diskus yang melibatkan 2/3 vertebrae), serta tindakan dekompresi. ${ }^{4}$ Tindakan ini tergolong dalam operasi yang menyebabkan kerusakan jaringan cukup besar, menimbulkan nyeri hebat yang dapat memicu peningkatan stres hormon (salah satunya hormon kortisol) yang dapat meningkatkan komplikasi dan mortalitas post operasi. ${ }^{1,4,5}$ Penggunaan analgesia opioid dalam jumlah besar diketahui memiliki efek samping bervariasi dan merugikan, namun penggunaan opioid dalam jumlah besar pada operasi tulang belakang sulit untuk dihindarkan. Oleh karena itu diperlukan suatu adjuvant anestesi lain untuk dapat mengurangi penggunaan opioid sehingga efek samping opioid pasca operasi dapat dikurangi. ${ }^{6,7}$ Dexmedetomidine (DEX) adalah senyawa agonis adrenoreseptor $\alpha 2$ yang sangat selektif dan spesifik, dengan tingkat selektivitas agonis $\alpha 2$ adrenergik yang sangat tinggi ( $\alpha 2$ : $\alpha 1=1620: 1){ }^{8}$ DEX juga bekerja dengan menurunkan aktivitas sistem saraf simpatis pusat melalui aksis HPA dan tingkat kewaspadaan. Hal tersebut menyebabkan DEX memiliki efek anxiolisis, sedatif, dan analgesia yang poten. Penggunaan DEX perioperatif dapat menurunkan respon pro-inflamasi akibat pembedahan. Penggunaan DEX mempengaruhi mekanisme terjadinya proses immunostimulatory dan immunosuppressive pasien dengan menurunkan respon stres melalui pengendalian hemodinamik dan nyeri perioperatif., ${ }^{9}$ Hal ini tentunya akan sangat mendukung kecepatan waktu penyembuhan sesuai dengan algoritma ERAS. Pada penelitian ini, peneliti ingin mengetahui mengenai efek penambahan DEX terhadap respon stres pembedahan yakni respon simpatoadrenal pada operasi besar tulang belakang. Respon stress diukur melalui pengukuran respon otonom yakni rerata tekanan arteri (MAP: Mean Arterial Pressure) dan laju nadi, yang diamati terutama pada saat intubasi endotrakea, prone positioning, dan insisi pembedahan serta mengetahui efektifitas DEX dalam pengurangan kebutuhan opioid (fentanyl) obat anestesi inhalasi (isoflurane) dalam pemeliharaan anestesi. Selain itu, peneliti juga mengukur salah satu respon stres akibat pembedahan melalui stres endokrin yang ditandai dengan perubahan hormon kortisol.

\section{Metode}

Penelitian ini merupakan penelitian experimental double blind randomized yang dilakukan di RSUD Dr. Soetomo Surabaya. Populasi penelitian adalah pasien dewasa yang menjalani operasi besar tulang belakang elektif dengan posisi telungkup. Dua puluh pasien melalui randomisasi dibagi menjadi kelompok yang mendapat perlakuan dexmedetomidine (DEX) dan placebo saline (SAL). Kriteria inklusi sampel penelitian adalah dewasa usia 17-60 tahun, keadaan status fisik ASA 1-2, merupakan pasien yang akan menjalani operasi besar tulang belakang (salah satu dari tindakan: fusi $\geq 2$ level diskus atau 1 level diskus yang melibatkan $2 / 3$ vertebrae, fusi spinal 360 derajat dengan insisi tunggal, pendekatan operasi kombinasi teknik anterior dengan transverse atau teknik fusi posterior, tindakan dekompresi), merupakan pasien dengan 
kelainan tulang belakang yang disertai destruksi jaringan (trauma, tuberculosis, dan degeneratif), jadwal pembedahan pagi hari, serta bersedia ikut dalam penelitian. Kriteria eksklusi sampel penelitian adalah pasien dengan kelainan anatomi, fungsi dan irama jantung, riwayat gangguan penyumbatan pembuluh darah jantung atau cerebral, terapi kortikosteroid dalam 2 minggu sebelum dilakukan pembedahan, terapi obat $\alpha$ dan atau $\beta$ agonis atau antagonis dalam 2 minggu sebelum dilakukan pembedahan, gangguan hepar dan atau ginjal sebelumnya, obesitas atau gizi buruk, serta pasien hamil dan menyusui. Kriteria drop out sampel penelitian adalah pasien dengan intubasi endotrakeal dilakukan lebih dari 1x percobaan dan perdarahan selama operasi lebih dari $40 \%$ EBV serta pembedahan yang memanjang $(>7$ jam).

Kelompok DEX mendapatkan dexmedetomidine $200 \mu \mathrm{g}$ yang dilarutkan menjadi $4 \mu \mathrm{g} / \mathrm{ml}$ dalam spuit $50 \mathrm{ml}$, sementara kelompok SAL mendapatkan saline dalam spuit $50 \mathrm{ml}$. Spuit 50 $\mathrm{ml}$ tersebut, diberi kode yang hanya diketahui oleh pihak farmasi, tidak diketahui oleh pasien, peneliti maupun anestetis yang melakukan pembiusan. Kedua kelompok mendapatkan premedikasi estazolam $2 \mathrm{mg}$ malam sebelum pembedahan dan cairan kristaloid pengganti puasa. Di ruang premedikasi dilakukan penilain nyeri dengan Wong Baker Faces Scale, tingkat kecemasan dengan Anxiety Faces Scale, serta pengambilan sampel kortisol darah preoperatif.

DEX/SAL loading dose $1 \mu \mathrm{g} / \mathrm{kg}$ iv selama 10 menit diberikan sebelum intubasi, lalu dilanjutkan dengan intubasi endotrakea 5 menit setelah loading dose selesai yang difasilitasi dengan fentanyl $1,5 \mu \mathrm{g} / \mathrm{kgBB}$, propofol $1 \mathrm{mg} / \mathrm{kgBB}$ dan rocuronium $0.8 \mathrm{mg} / \mathrm{kgBB}$. Pemeliharaan anestesi dilakukan dengan $\mathrm{O}_{2}+$ air $50 \%$, isoflurane mulai dari $1 \mathrm{MAC}$, fentanyl 1,5 $\mu \mathrm{g} / \mathrm{kgBB} / \mathrm{jam}$ dan DEX/ SAL $0,5 \mu \mathrm{g} / \mathrm{kg} / \mathrm{jam}$ via syringe pump. Apabila terjadi bradikardia (nadi $<50 \mathrm{x} / \mathrm{m}$ ), diberikan bolus sulfas atropine $0,5 \mathrm{mg}$ iv dan dosis pemeliharaan DEX/SAL dikurangi $0,1 \mu \mathrm{g} / \mathrm{kg} / \mathrm{jam}$. Dan apabila terjadi hipotensi (TD $<90 / 50 \mathrm{mmHg}$ dan atau penurunan $\mathrm{MAP}<20 \%$ MAP awal), diberikan ephedrin $10 \mathrm{mg}$ i.v. Nadi dan MAP dicatat saat 1 menit sebelum intubasi (T-1), saat laryngoscopy
(T0), dan menit ke-1 (T1), ke-3 (T3), ke-5 (T5) setelah dilakukan intubasi endotrakea, prone positioning, dan insisi. Apabila selama 30 menit hemodinamik didapatkan stabil, kecepatan infus fentanyl diturunkan 25\%, dan apabila didapatkan peningkatan nadi dan tekanan darah sebanyak $20 \%$ selama 2 menit berturut-turut tanpa pengurangan MAC anestesi inhalasi sebelumnya, diberikan rescue analgesia yakni bolus fentanyl $1 \mu \mathrm{g} / \mathrm{kgBB}$ i.v. Anestesi inhalasi Isoflurane digunakan pada kedua kelompok dan apabila tidak ada peningkatan nadi maupun tekanan darah akibat stimulasi pembedahan dalam jeda waktu 15 menit, maka MAC diturunkan sebanyak 20\%. Kebutuhan fentanyl dan isoflurane dititrasi selama pembedahan dan dihitung rerata penggunaan nya selama pembedahan. Saat selesai jahit kulit, infus kontinyu fentanyl dan DEX/SAL dihentikan, serta dilakukan pemberian analgesia pasca bedah dan reversal agent. Pasca pembedahan pasien di monitoring di ruang pemulihan, waktu pemulihan dari anestesi diukur melalui skor Aldrette dan dilakukan pengambilan sampel kortisol darah 1 jam setelah selesai pembedahan. Perbedaan kadar kortisol darah diukur dari delta kortisol post operatif dan pre-operatif.

\section{Hasil}

Penelitian ini termasuk penelitian eksperimen klinik dengan randomisasi tersamar dua pihak, membagi subyek menjadi dua kelompok yaitu kontrol (SAL) dan perlakuan (DEX). Kelompok perlakuan adalah kelompok DEX yakni pasien yang mendapat dexmedetomidine (DEX/FEN/ ISO) dan kelompok kontrol adalah kelompok SAL yang mendapatkan obat placebo saline (SAL/ FEN/ISO), dimana masing-masing kelompok terdiri 10 subyek penelitian yang menjalani operasi besar tulang belakang elektif di RSUD Dr. Soetomo. Karakteristik basal antara kedua kelompok (Tabel 1) tidak didapatkan perbedaan yang bermakna, termasuk tingkat nyeri dan cemas antara kedua kelompok. Loading dose obat yang dilakukan pada saat awal penelitian, memberikan efek perbedaan yang bermakna pada nadi $(\mathrm{p}=0,01$ pada 5 menit pertama dan $\mathrm{p}=0,001$ pada 10 menit terakhir), dimana tampak kelompok DEX memiliki nadi yang lebih 
Tabel 1. Karakteristik Subyek Penelitian

\begin{tabular}{|c|c|c|c|}
\hline Karakteristik Subyek & DEX & SAL & $\mathbf{P}$ \\
\hline Usia (tahun) & $44,3 \pm 10,49$ & $42.1 \pm 14,23$ & 0,741 \\
\hline Jenis Kelamin & & & 0,655 \\
\hline Laki - laki & $4(40 \%)$ & $6(60 \%)$ & \\
\hline Perempuan & $6(60 \%)$ & $4(40 \%)$ & \\
\hline Etiologi Penyakit Tulang Belakang & & & 0,734 \\
\hline Degenerative & $2(20 \%)$ & $2(20 \%)$ & \\
\hline Tuberkulosis (TB) & $4(40 \%)$ & $4(40 \%)$ & \\
\hline Trauma & $3(30 \%)$ & $4(40 \%)$ & \\
\hline Tumor & $1(10 \%)$ & $0(0 \%)$ & \\
\hline Skala Nyeri Pre-operative (WBFS) & & & 0,412 \\
\hline Tidak nyeri & $4(40 \%)$ & $2(20 \%)$ & \\
\hline Sedikit nyeri & $4(40 \%)$ & $6(60 \%)$ & \\
\hline Sedikit lebih nyeri & $2(20 \%)$ & $0(0 \%)$ & \\
\hline Lebih nyeri & $0(0 \%)$ & $2(20 \%)$ & \\
\hline Lama Pembedahan (jam) & $4,26 \pm 1,47$ & $4.9 \pm 1,78$ & 0,385 \\
\hline Jumlah Perdarahan (\% EBV) & $14 \pm 10$ & $15.8 \pm 12,8$ & 0,733 \\
\hline \multicolumn{4}{|c|}{ Hemodinamik saat Loading Dose selama 10 menit } \\
\hline \multicolumn{4}{|l|}{ 5' pertama } \\
\hline Nadi & $76,4 \pm 9,13$ & $97 \pm 14,45$ & 0,01 \\
\hline MAP & $89,93 \pm 13,25$ & $94,5 \pm 6,55$ & 0,342 \\
\hline \multicolumn{4}{|l|}{$10^{\prime}$ terakhir } \\
\hline Nadi & $69,4 \pm 5.66$ & $96 \pm 13,8$ & 0,001 \\
\hline MAP & $83,86 \pm 14.4$ & $93.86 \pm 7,69$ & 0,074 \\
\hline
\end{tabular}

Keterangan: TB=Tuberkulosis; WBFS= Wong Baker Faces Scale; EBV= Estimated Blood Volume

rendah dibanding kelompok SAL. Serta adanya perbedaan penurunan diastolik bermakna pada 10 menit terakhir $(\mathrm{p}=0,031)$. Didapatkan nadi basal sebelum tindakan (T-1) tidak berbeda antara kedua kelompok, (Tabel 2) dan perbedaan nadi yang lebih rendah bermakna antara kelompok DEX dan SAL pada hampir seluruh pencatatan pada saat atau setelah tindakan dengan $\mathrm{p}<0,05$ (Tabel 2). Perbandingan MAP ditunjukkan pada Tabel 3 dimana pada 1 menit sebelum intubasi dan insisi (baseline) antara kedua kelompok didapatkan tidak berbeda dengan nilai $\mathrm{p}>0,05$. Namun pada saat dilakukan laringoskopi (T0) hingga menit ke-5 setelah intubasi atau insisi (T5), didapatkan perbedaan yang bermakna antara kedua kelompok $(\mathrm{p}<0,05)$. MAP pada subyek penelitian sebelum dilakukan prone positioning didapatkan sama antar kedua kelompok. Dari tabel diatas tampak tidak ada perbedaan bermakna baik pada sistolik, diastolik maupun MAP antara kelompok DEX dan SAL pada menit ke- 1, 3 dan 5 setelah melakukan prone positioning $(\mathrm{p}>0,05)$. Kelompok DEX memiliki parameter hemodinamik (Nadi, Sistole, Diastole dan MAP) yang lebih stabil dibandingkan kelompok SAL. (Gambar 4). Tampak gejolak nadi dan MAP yang bermakna sebelum dan sesudah tindakan pada kelompok kontrol. Penambahan dexmedetomidine tidak menimbulkan gejolak hemodinamik yang bermakna pada saat prone positioning. Penggunaan fentanyl pada kedua kelompok menunjukkan perbedaan bermakna dengan nilai $\mathrm{p}<0,05$. Rerata rumatan fentanyl pada kelompok DEX dibutuhkan sebanyak $0,74 \mu \mathrm{g} / \mathrm{kgBB} / \mathrm{jam}$. Sedangkan pada Kelompok SAL dibutuhkan dosis pemeliharaan fentanyl sebanyak 2x lipat kelompok DEX, yakni 1,6 
Tabel 2. Perbandingan Nadi saat Intubasi, Prone Positioning dan Insisi

\begin{tabular}{llll}
\hline Nadi $(\mathbf{x} / \mathbf{m})$ & DEX & \multicolumn{1}{l}{ SAL } & P \\
\hline Perbandingan nadi saat Intubasi & & \\
T-1 & $71,7 \pm 8,16$ & $86,0 \pm 15,12$ & 0,017 \\
T0 & $73,3 \pm 7,96$ & $107 \pm 18,15$ & 0,001 \\
T1 & $76 \pm 7,88$ & $110,1 \pm 19,57$ & 0,001 \\
T3 & $73,6 \pm 7,51$ & $102,3 \pm 17,44$ & 0,001 \\
T5 & $71.2 \pm 8,06$ & $95,8 \pm 14,09$ & 0,001 \\
Perbandingan nadi saat prone positioning & & \\
T-1 & $75,2 \pm 10,79$ & $88.0 \pm 16.46$ & 0,055 \\
T1 & $78,1 \pm 11,3$ & $95.8 \pm 17,38$ & 0,015 \\
T3 & $75,7 \pm 11,23$ & $96.0 \pm 15.32$ & 0,003 \\
T5 & $75,0 \pm 10,55$ & $91.6 \pm 16.09$ & 0,014 \\
Perbandingan nadi saat insisi & & \\
T-1 & $71,6 \pm 9,33$ & $83,1 \pm 19,29$ & 0,107 \\
T1 & $73,6 \pm 8,47$ & $95,9 \pm 24,57$ & 0,02 \\
T3 & $73,3 \pm 8,57$ & $94,5 \pm 24,34$ & 0,024 \\
T5 & $73,6 \pm 9,19$ & $89,9 \pm 19,88$ & 0,035 \\
\hline
\end{tabular}

Keterangan: T-1 $=1$ menit sebelum intervensi, $\mathrm{T} 0=$ pada saat laringoskopi pada intubasi, $\mathrm{T} 1=1$ menit setelah intervensi, T3 $=3$ menit setelah intervensi, T5 $=5$ menit setelah intervensi

Tabel 3. Perbandingan MAP pada Intubasi, Prone Positioning dan Insisi

\begin{tabular}{llll}
\hline Waktu & MAP $(\mathbf{m m H g})$ & & \\
\hline Intubasi & DEX & SAL & P \\
$\mathrm{T}_{1}$ & $83,9 \pm 11,69$ & $82,8667 \pm 6,59$ & 0,810 \\
T0 & $86,53 \pm 13,25$ & $107,2 \pm 14,34$ & 0,004 \\
T1 & $83,43 \pm 13,25$ & $102,8 \pm 10,35$ & 0,002 \\
$\mathrm{~T}_{3}$ & $80,03 \pm 11,55$ & $92,37 \pm 9,57$ & 0,018 \\
T5 & $76,37 \pm 9,32$ & $85,57 \pm 8,30$ & 0,032 \\
Prone Positioning & & & \\
$\mathrm{T}_{-1}$ & $77,8 \pm 10,33$ & $87,03 \pm 10,17$ & 0,059 \\
T1 & $78,4 \pm 9,76$ & $84,4 \pm 17,28$ & 0,352 \\
T3 & $78,5 \pm 9,16$ & $82,03 \pm 8,35$ & 0,379 \\
T5 & $79,9 \pm 10,85$ & $81,26 \pm 8,91$ & 0,762 \\
Insisi & & & \\
T-1 & $75,6 \pm 7,97$ & $80,0 \pm 7,22$ & 0,212 \\
T1 & $77,76 \pm 7,69$ & $93,36 \pm 13,08$ & 0,006 \\
T3 & $77,86 \pm 9,62$ & $91,56 \pm 12,98$ & 0,015 \\
T5 & $77,7 \pm 5,52$ & $87,86 \pm 11,32$ & 0,024 \\
\hline
\end{tabular}


Nadi

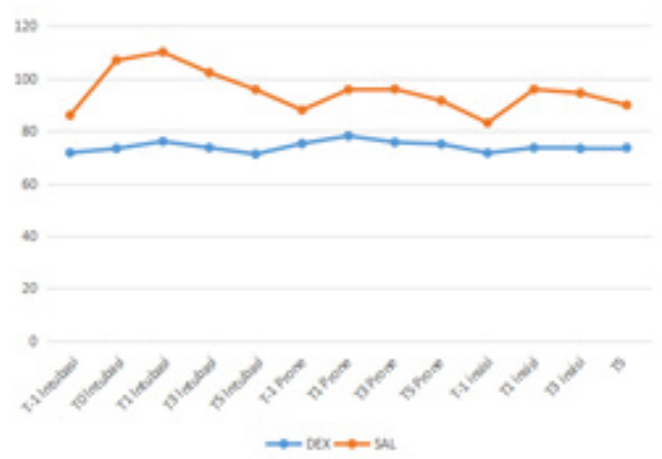

A

Diastolik

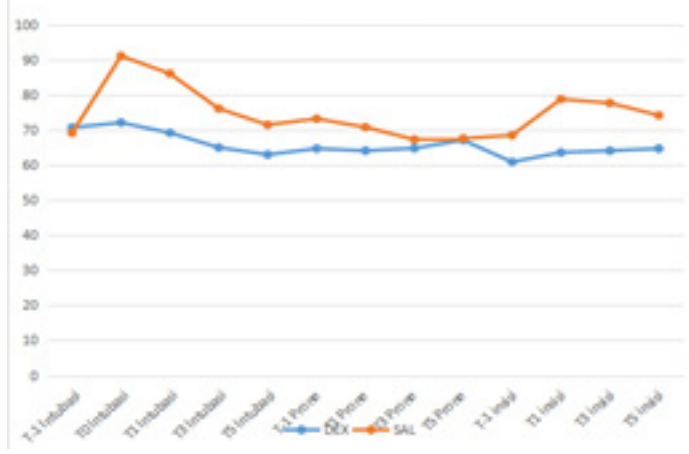

$\mathrm{C}$

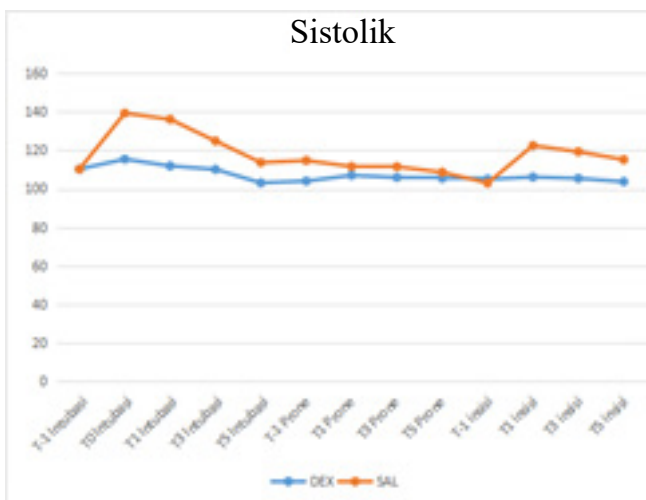

B

MAP

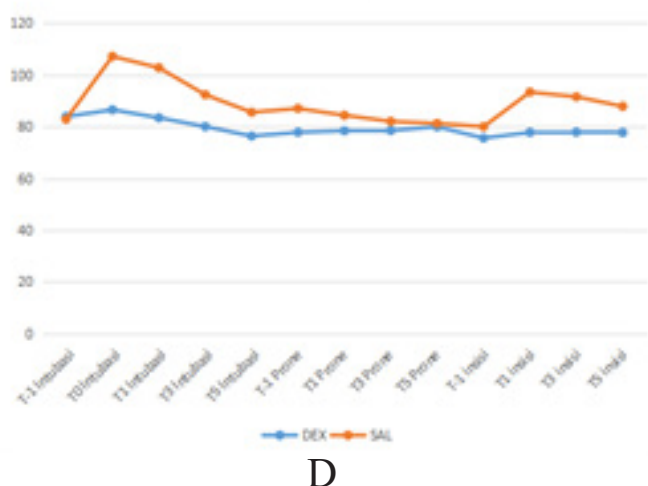

D

Gambar 1-4. Grafik Perbandingan Nadi (A), Sistole (B), Diastole (D) dan MAP (D) antara DEX dan SAL: Hemodinamik yang lebih stabil didapatkan pada Kelompok DEX

Tabel 4. Perubahan Nadi dan MAP sebelum dan sesudah Intubasi, Prone Positioning dan Insisi

\begin{tabular}{lllll}
\hline Parameter & Kelompok & (T-1) & (T5) & Harga p \\
\hline Intubasi & & & & \\
NADI (x/m) & DEX & $71,7 \pm 8,2$ & $71,2 \pm 8,1$ & $* 0,762$ \\
& SAL & $86,0 \pm 15,1$ & $95.8 \pm 14.1$ & 0,010 \\
MAP (mmHg) & DEX & $83,9 \pm 11,7$ & $76.4 \pm 9,3$ & $* 0,081$ \\
& SAL & $82,8 \pm 6,6$ & $76,4 \pm 9,3$ & $* 0,411$ \\
Prone Positioning & & & & \\
NADI (x/m) & DEX & $75,2 \pm 10,7$ & $75,0 \pm 10.5$ & $* 0,936$ \\
& SAL & $88,0 \pm 16,4$ & $91.6 \pm 16,1$ & $* 0,147$ \\
MAP (mmHg) & DEX & $77,8 \pm 10,3$ & $79,9 \pm 10,8$ & $* 0,383$ \\
& SAL & $87,0 \pm 10,2$ & $81,3 \pm 8,9$ & $* 0,091$ \\
Insisi & & & & \\
NADI (x/m) & DEX & $71,6 \pm 9,3$ & $73,6 \pm 9,2$ & $* 0,090$ \\
& SAL & $83,1 \pm 19,3$ & $89,9 \pm 19,8$ & 0,003 \\
MAP (mmHg) & DEX & $75,6 \pm 7,9$ & $77,7 \pm 5,5$ & $* 0,236$ \\
& SAL & $80,0 \pm 7,2$ & $87,6 \pm 11,3$ & 0,014 \\
\hline
\end{tabular}

*) Tidak berbeda bermakna ( $p>0.05)$ 
Tabel 5. Perbandingan Penggunaan Fentanyl dan Isoflurane

\begin{tabular}{|c|c|c|c|}
\hline & DEX & SAL & $\mathrm{P}$ \\
\hline \multicolumn{4}{|c|}{ Penggunaan Fentanyl } \\
\hline $\begin{array}{l}\text { Fentanyl Rumatan } \\
\text { (mcg/kgBB/jam) }\end{array}$ & $0.74 \pm 0.3$ & $1.6 \pm 0.4$ & 0.000 \\
\hline $\begin{array}{l}\text { Frekuensi Rescue } \\
\text { Fentanyl (kali) }\end{array}$ & $0.5 \pm 0.7$ & $3.3 \pm 2.4$ & 0.004 \\
\hline \multicolumn{4}{|c|}{ Penggunaan Isoflurane } \\
\hline \multicolumn{4}{|l|}{ Skor Aldrette } \\
\hline $\begin{array}{l}\text { Skor Awal (menit } \\
\text { ke-0) }\end{array}$ & $9.33 \pm 0.86$ & $8.0 \pm 0.0$ & 0.002 \\
\hline $\begin{array}{l}\text { Kecepatan } \\
\text { mencapai skor } \\
\text { penuh (menit) }\end{array}$ & $15 \pm 21.21$ & $90 \pm 32.07$ & 0.001 \\
\hline \multicolumn{4}{|l|}{ Kortisol } \\
\hline $\begin{array}{l}\text { Perubahan } \\
\text { Kortisol (mcg/dl) }\end{array}$ & $9.9 \pm 5.2$ & $11.7 \pm 8.4$ & 0.880 \\
\hline
\end{tabular}

$\mu \mathrm{g} / \mathrm{kgBB} / \mathrm{jam} \quad(\mathrm{p}=0,000)$. Frekuensi rescue analgesia selama pembedahan juga berbeda bermakna yakni pada Kelompok DEX hampir tidak dibutuhkan rescue analgesia selama pembedahan, sedangkan pada Kelompok SAL dibutuhkan 3,3 $\pm 2,4$ pemberian rescue analgesia fentanyl $(p=0,004)$. Rerata penggunaan dosis pemeliharaan anestesi inhalasi isoflurane pada Kelompok DEX adalah 0,7 MAC, lebih rendah $30 \%$ jika dibandingkan dengan Kelompok SAL yakni 1 MAC $(\mathrm{p}=0,000)$. Skor Aldrette awal (menit ke-0) antara kedua kelompok didapatkan berbeda bermakna, dimana rerata skor aldrette awal pada kelompok DEX adalah 9,33 dan pada kelompok SAL adalah 8, dengan harga $\mathrm{p}=0,002$. Kecepatan mencapai Skor Aldrette penuh juga didapatkan lebih cepat pada kelompok DEX ( $p$ $=0,001$ ). Didapatkan perubahan kadar kortisol, yakni selisih antara kortisol post operatif dan pre-operatif, pada kelompok DEX lebih rendah namun nilai tersebut secara statistik didapatkan tidak berbeda bermakna $(p>0,05)$.

\section{Pembahasan}

Pengamatan saat tindakan intubasi, didapatkan nadi 1 menit sebelum intubasi pada kelompok
DEX lebih rendah bermakna dari kelompok SAL. Hal ini dikarenakan kelompok DEX telah mendapat loading dose dexmedetomidine yang memberikan aksi vagomimetic terhadap denyut jantung yakni penurunan laju nadi. Respon hemodinamik lain yakni MAP, menunjukkan perbedaan yang juga signifikan pada menit ke-0 hingga menit ke 5, dimana tampak adanya peningkatan MAP pada kelompok SAL (Tabel 3). Akan tetapi ada analisa perubahan MAP pada sebelum (T-1) dan sesudah intubasi (T5), MAP kedua kelompok secara statistik tidak mengalami perubahan yang bermakna. Hal ini berarti dengan penambahan dexmedetomidine, nadi dan MAP dapat dipertahankan tetap stabil, tanpa ada nya gejolak saat dilakukan laringoskopi hingga intubasi endotrakea. Laringoskopi dan intubasi hampir selalu menyebabkan peningkatan respon hemodinamik, telah banyak penelitian yang bertujuan untuk mengontrol respon tersebut. Dexmedetomidine didapatkan lebih superior dalam mencegah respon takikardi dibandingkan esmolol. ${ }^{14}$ Pre-treatment dexmedetomidne $1 \mu \mathrm{g} /$ $\mathrm{kgBB}$ selama 15 menit sebelum intubasi juga dilakukan oleh Menda dkk pada pasien operasi CABG (Coronary Arterial Bypass Graft), dengan hasil adanya perbedaan peningkatan nadi yang bermakna pada kelompok saline dibandingkan dengan kelompok dexmedetomidine. ${ }^{15}$ Pada penelitian ini pemberian dexmedetomidine tidak menghasilkan perbedaan yang bermakna antara nadi dan MAP sebelum dan sesudah positioning antara kedua kelompok.

Hal ini membuktikan bahwa penambahan dexmedetomidine dapat tetap menjaga kestabilan laju nadi dan MAP pada saat dilakukan posisi prone. Secara umum, aktivasi presinaptik dari $\alpha 2$-adrenoceptor menghambat keluarnya norepinephrine dan mengakhiri signal nyeri. Sedangkan postsinaptik dari $\alpha 2$-adrenoceptor pada sistem saraf pusat menghambat aktivitas simpatis dan meningkatkan respon vagal. Selain itu dexmedetomidine di tingkat perifer memiliki aksi menghambat ganglion simpatis sehingga meningkatkan efek simpatolisis. Pengamatan pada saat insisi pembedahan, juga didapatkan perbedaan yang bermakna antara kedua kelompok dimana hampir tidak ada peningkatan 
nadi dan MAP yang bermakna pada kelompok DEX. Secara keseluruhan cara kerja dari $\alpha 2$ adrenoceptor cukup signifikan mengurangi katekolamin dalam tubuh, sehingga menghambat peningkatan tekanan darah dan nadi secara bermakna. Pada penelitian ini didapatkan kedua kelompok mengalami peningkatan kadar hormon kortisol, dimana perubahan kortisol pre dan post operasi pada kelompok dexmedetomidine lebih rendah dibandingkan placebo.

Sebuah meta-analisis menunjukkan penggunaan dexmedetomidine perioperatif dapat mengurangi kadar kortisol dan katekolamin dalam darah dan perbedaan ini cukup signifikan jika dibandingkan dengan placebo, namun tidak signifikan jika dibandingkan dengan obat anestesi perioperatif lainnya. ${ }^{5}$ Dexmedetomidine melalui aktivasi $\alpha 2$ adrenoceptor di medulla spinalis memberikan efek opioid sparing. Pada penelitian ini, penambahan dexmedetomidine $0,5 \mu \mathrm{g} / \mathrm{kgBB} /$ jam pada penggunaan fentanyl $1,5 \mu \mathrm{g} / \mathrm{kgBB} /$ jam, memiliki efek sinergis. Terbukti dengan pengurangan total dosis pemberian fentanyl pada subyek penelitian. Pemberian rumatan fentanyl pada kelompok DEX dapat dititrasi turun hingga off, dengan rerata dosis rumatan $0,75 \mu \mathrm{g} / \mathrm{kgBB} / \mathrm{jam}$ dan hampir tidak memerlukan tambahan rescue analgesia selama pembedahan. Hal tersebut didapatkan berbeda bermakna pada kelompok kontrol yang hanya menerima analgesia fentanyl, dimana dibutuhkan dosis pemeliharaan fentanyl hingga $2 x$ lebih besar dan penambahan rescue analgesia lebih sering selama operasi. Penambahan dexmedetomidine juga memberikan penurunkan rerata kebutuhan MAC anestesi inhalasi isoflurane. Hal tersebut sesuai dengan mekanisme kerja dexmedetomidine di locus cereleus sebagai pusat kewaspadaan tertinggi yang memberikan efek sedasi sinergis dengan anestesi inhalasi. Modulasi dari respon endokrin, metabolik dan inflamasi mungkin dapat menurunkan kelelahan pascabedah dan memperpendek waktu pemulihan. ${ }^{16}$ Pengamatan kecepatan pulih sadar melalui skor aldrette di ruang pemulihan pasca anestesi, mengungkapkan bahwa pada kelompok DEX didapatkan skor aldrette awal yang lebih tinggi serta kecepatan mencapai skor Aldrette penuh didapatkan lebih cepat pada kelompok DEX. Hal ini dapat disebabkan oleh akibat penambahan DEX yang menurunkan total kebutuhan gas anestesi maupun opioid selama pembedahan sehingga secara tidak langsung dexmedetomidine dapat memberikan waktu pulih sadar dari anestesi lebih cepat.

\section{Simpulan}

Penambahan dexmedetomidine memberikan kestabilan nadi dan MAP yang bermakna pada saat intubasi endotrakea, prone positioning dan insisi pada pasien operasi besar tulang belakang. Penambahan dexmedetomidine juga menyebabkan penurunan kebutuhan analgesia opioid fentanyl yang bermakna hingga $2 \mathrm{x}$ lebih rendah dan pengurangan rerata MAC isoflurane sebanyak $30 \%$ selama operasi, sehingga memberikan proses pemulihan dari anestesi yang lebih cepat. Respon stres endokrin yang ditandai dengan perubahan kadar kortisol pada operasi besar tulang belakang didapatkan lebih rendah akibat penambahan dexmedetomidine.

\section{Daftar Pustaka}

1. Farag E. Anesthesia for spine surgery. New York: Cambridge University Press, 2012.

2. Nicholson A, Lowe MC, Parker J. Systematic review and meta-analysis of enhanced recovery programmes in surgical patients. $\mathrm{Br}$ J Surg 2014, 101:172-88.

3. Nirav V, Kamdar, Hoftman N, Rahman S, Cannesson M. Opioid-free analgesia in the era of enhanced recovery after surgery and the surgical home: implications for postoperative outcomes and population health. International Anesthesia Research Society. 2017.

4. Wainwright $\mathrm{TW}$, Immins $\mathrm{T}$, Middleton RG. Enhanced Recovery After Surgery (ERAS) and its applicability for major spine surgery. Best Practice \& Research Clinical Anaesthesiology. 2015.

5. Wang X, Cao J, Lv B. Effect of perioperative dexmedetomidine on the endocrine 
modulators of stress response: a metaanalysis. Clin Exp Pharmacol Physiol, 2015, 42(8):828-36.

6. Carli F, Baldini G. Perioperative pain management and enhance outcomes. In: Mikhail MS, Murray MJ, Morgan GE. Clinical Anaesthesiology, 5th edition. New York: Mc Graw Hill, 2013.

7. Mathieson O, Dahl B and Thomsen BA. A comprehensive multimodal pain treatment reduces opioid consumption after multilevel spine surgery. Eur Spine J. 2013, 22: 208996.

8. Stoelting R. Pharmacology and Physiology in Anaesthetic Practice, 5th edition. Philadelphia: Wolters Kluwer Health, 2015.

9. Li B, Yalan L, Tian S, Wang H, Wu H, et al. Anti-inflammatory effects of perioperative dexmedetomidine administered as an adjunct to general anesthesia: a metaanalysis. Scientific Reports. 2015.

10. Anderson SL, Duke-Novakovski T, Baljit S. The immune response to anesthesia: Part 2 sedatives, opioids, and injectable anesthetic agents. Veterinary Anaesthesia and Analgesia, 2014; 41:553-66.

11. Bekker A, Haile M, Kline R, Didehvar S. The effect of intraoperative infusion of dexmedetomidine on the quality of recovery after major spinal surgery. J Neurosurg Anesthesiol. 2013; 25(1).
12. Gupta N, Rath G, Prabhakar H. Effect of intraoperative dexmedetomidine on postoperative recovery profile of children undergoing surgery for spinal dysraphism. $\mathrm{J}$ Neurosurg Anesthesiol. 2013 July:25(3):27178.

13. Bojaraaj K, Senthilkumar S, Vijayaragavan S, Gnanavelrajan A. Effect of Intravenous use of Dexmedetomidine on Anesthetic Requirements in Patients Undergoing Elective Spine Surgery: A Double Blinded Randomized Controlled Trial. International Journal of Spinal Surgery. 2014; 4(2): 25155.

14. Gogus N, Akan B, Serger N, Baydar M. The comparison of the effects of dexmedetomidine, fentanyl and esmolol on prevention of hemodynamic response to intubation. BJAN. 2013; 64(5):314-19.

15. Menda F, Köner Ö, Sayın M, Türe H. Dexmedetomidine as an adjunct to anesthetic induction to attenuate hemodynamic response to endotracheal intubation in patients undergoing fast-track CABG. Annals of Cardiac Anaesthesia. 2010, 13:1.

16. Yacout A, Osman H, Abdel-Daem M. Effect of intravenous dexmedetomidine infusion on some proinflammatory cytokines, stress hormones and recovery profile in major abdominal surgery. Alexandria J Med. 2012; 48:3-8. 